\title{
The volatile organic compound profile of ripened cheese is influenced by crude protein shortage and conjugated linoleic acid supplementation in the cow's diet
}

\author{
Qianlin Ni, ${ }^{1}$ Flavia Gasperi, ${ }^{2}$ () Eugenio Aprea, ${ }^{2}$ ๑) Emanuela Betta, ${ }^{2}$ Matteo Bergamaschi, ${ }^{1}{ }^{\circ}$

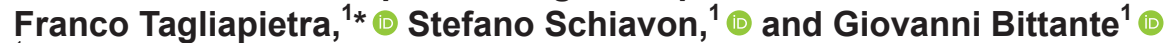 \\ ${ }^{1}$ Department of Agronomy, Food, Natural Resources, Animals and the Environment (DAFNAE), University of Padua, Viale dell'Università 16, \\ 35020 Legnaro (PD), Italy \\ ${ }^{2}$ Department of Food Quality and Nutrition, Research and Innovation Centre, Fondazione Edmund Mach (FEM), Via E. Mach 1 , \\ 38010 San Michele all'Adige (TN), Italy
}

\section{ABSTRACT}

A shortage in crude protein (CP) and supplementation of conjugated linoleic acids (CLA) in the diets of dairy cows could improve the dairy industry's ecological footprint and the nutritional value of milk, but it is not known what effect such a strategy might have on the aroma profiles of dairy products. The aim of this work was to study the effects of reducing the dietary $\mathrm{CP}$ content (from 150 to $123 \mathrm{~g} / \mathrm{kg}$ of dry matter), with or without a supply of rumen-protected CLA $(7.9 \mathrm{~g} / \mathrm{d}$ C18:2 cis-9,trans- 11 and $7.7 \mathrm{~g} / \mathrm{d}$ C18:2 trans-10,cis-12), on the volatile organic compound (VOC) profile of cheeses ripened for 3 mo. Twenty mid-lactation Holstein-Friesian cows were reared in 4 pens ( 5 to a pen), and fed 4 different experimental diets over 4 periods of 3 wk each, following a $4 \times 4$ Latin square design. Twice in each period, 10-L milk samples were taken from each group and used to produce 32 cheeses, which we then analyzed for VOC by solid-phase microextraction and gas chromatography-mass spectrometry. We detected 48 VOC belonging to 10 chemical classes (11 alcohols, 8 ketones, 8 esters, 7 acids, 4 aldehydes, 4 sulfurs, 2 lactones, 2 phenolic, 1 monoterpene, 1 hydrocarbon); these were expressed as concentrations in cheese (quantitative data) or as proportions of total VOC (qualitative data). The results of mixed model analysis showed that the majority of VOC families and individual VOC in ripened cheese were affected by the dietary treatments: CP shortage depressed the concentrations of volatile aldehydes and increased the proportions of some esters and limonene, whereas CLA increased the concentration of total VOC, particularly several acids and esters,

Received February 14, 2019.

Accepted October 5, 2019.

*Corresponding author: franco.tagliapietra@unipd.it and decreased the proportions of ketones and phenolic compounds. The interaction between dietary $\mathrm{CP}$ and CLA affected the proportions of alcohols and acids. We performed a factor analysis to extract 5 latent explanatory variables from the individual VOC, which represented $79 \%$ of total VOC variance for the quantitative data and $78 \%$ for the qualitative data. Addition of CLA decreased the first qualitative factor (the "base aroma" of cheese, explaining $44 \%$ of total variance), whereas $\mathrm{CP}$ reduction increased the second quantitative factor ("ethyl esters," $15 \%$ of total variance) and the third qualitative factor ("butan-," $9 \%$ of total variance). In summary, the VOC profile of ripened cheese was heavily influenced by CP content and CLA supplementation in the diets of dairy cows, but the effect on sensorial properties of cheese is also worth considering.

Key words: low-protein diet, conjugated linoleic acid, CLA, latent explanatory factor, volatile organic compounds

\section{INTRODUCTION}

Diets of lactating cows are traditionally formulated to meet nutrient requirements while minimizing cost. However, there is demand for feeding strategies that will reduce the environmental impact of dairy farms and improve the nutritional and sensory value of dairy products to the benefit of human health and well-being.

Nitrogen excreted with feces and urine together with greenhouse gas emissions have a major impact on the environment (Notarnicola et al., 2017). Reducing the $\mathrm{N}$ content in cows' diets can decrease $\mathrm{N}$ excretion (Huhtanen and Hristov, 2009; Arriola Apelo et al., 2014), but the quality of the milk may be affected. Leonardi et al. (2003), Cabrita et al. (2007), and Fanchone et al. (2013) showed that reducing dietary $\mathrm{CP}$ content had little or no effect on milk yield but slightly decreased the milk protein content and altered 
the fatty acid profile. These authors also suggested that there may be some interaction between protein content and lipid metabolism.

The CLA isomers are a group of fatty acids naturally occurring in foods derived from ruminants (Hennessy et al., 2016). Conjugated linoleic acid, of which the isomer C18:2 cis-9,trans-11 (rumenic acid) accounts for more than $80 \%$ (Chin et al., 1992), has been shown to provide a wide range of benefits to humans, having, for example, anticarcinogenic, antidiabetic, and immune stimulation properties (Calder, 2015; Ferlay et al., 2017; Li et al., 2018), although the mechanisms are not yet fully understood. Supplementing cows' rations with CLA could improve the fatty acid profile of their milk (Perfield et al., 2002; Coakley et al., 2007) and cheese (Schiavon et al., 2016) by decreasing the proportions of short- and medium-chain SFA and increasing long-chain MUFA and PUFA and CLA. Moreover, CLA seems to interact with the level of $\mathrm{CP}$ in the diet, improving feed utilization efficiency in low-protein diets (Park et al., 1997; Schiavon et al., 2010).

Changes in feeding strategy can alter rumen activity and metabolic and udder biosynthesis processes of cows, and these in turn can modify the properties of the milk and derived cheese, and hence their flavor and other sensory characteristics. Although dairy cow feeding systems, particularly pasture, have been shown to affect the sensory properties and volatile organic compound (VOC) profiles of milk and cheeses (Coulon et al., 2004; Hassan et al., 2012; O'Callaghan et al., 2017), little is known about the effects of dietary CP level and CLA supplementation on these. Cheese is the most important dairy product in Europe and it represents the destination of $75 \%$ of milk produced in some countries, such as Italy (IDF, 2018). Odor and flavor are probably the most important criteria for cheese choice and acceptance by consumers; these are less important in milk because of the degassing, deodorization, and heat treatment that occur before packaging (Drake, 2007; Bittante et al., 2011b). We demonstrated that, with respect to the milk used for cheese making, the sum of all VOC in the obtained cheese is increased $167 \%$ in curd, $2,890 \%$ in cheese ripened for $6 \mathrm{mo}$, and 4,303\% in cheese ripened for $1 \mathrm{yr}$ (Bergamaschi and Bittante, 2018). In particular, the VOC in ripened cheese (Molimard and Spinnler, 1996) are mainly driven by native milk fat, protein, lactose, and enzyme composition, and by several microbial and biochemical processes occurring during cheese ripening, such as glycolysis, lipolysis, and proteolysis (McSweeney and Sousa, 2000; Hassan et al., 2012). With a standardized cheesemaking procedure and starter culture, the variability of final cheese flavor depends especially on chemical, enzymatic, and microbiological characteristics of the milk processed (Coulon et al., 2004; Marilley and Casey, 2004).

We hypothesized that a reduction in CP, supplementation with CLA, or their possible interaction in the diet of dairy cows would alter the VOC profile of the cheese. The aim of this study, therefore, was to investigate the effects of this feeding strategy on ripened cheeses produced from the milk from lactating Holstein-Friesen dairy cows.

\section{MATERIALS AND METHODS}

This study is part of a larger research project on feeding low-protein diets and CLA supplements to dairy cows to analyze the effects on some of the animals' productive, digestive, and metabolic parameters (Schiavon et al., 2015), their fecal excretion and milk secretion of fatty acids (Schiavon et al., 2018), and fatty acid transfer to the ripened cheese (Schiavon et al., 2016). The Ethical Committee of the University of Padua (CEASA) approved all the animal experimental procedures, which were carried out in accordance with the Guide for the Care and Use of Agricultural Animals in Research and Teaching (FASS, 2010).

\section{Animals, Feeding System, and Experimental Design}

Details of the experimental design and the animals' characteristics, diets, production performance, $\mathrm{N}$ balances, and feeding systems are given in Schiavon et al. (2015). Briefly, 20 mid-lactation Holstein-Friesian cows were divided into 4 experimental groups balanced for milk yield, DIM, parity, BW, and BCS (Table 1). The groups were housed in separate pens with strawbedded cubicles, and the cows had 2 wk to adapt to the experimental conditions before the experiment began. Control cows (CP15) were fed TMR consisting of corn silage, ground corn grain, meadow hay, dried sugar beet pulp, alfalfa hay, soybean meal, wheat bran, and a mineral-vitamin supplement, formulated according to the requirements of dairy cows producing $30 \mathrm{~kg} / \mathrm{d}$ milk (NRC, 2001). A low-protein TMR (CP12) was obtained by replacing half the soybean meal with barley meal. The TMR of half the cows fed CP15 and half of those fed CP12 were top dressed and mixed with a CLA supplement $(80 \mathrm{~g} / \mathrm{d}$ per cow $)$ containing 7.9 $\mathrm{g} / \mathrm{d}$ C18:2 cis-9,trans-11 (CP15 CLA $_{\text {) }}$ or $7.7 \mathrm{~g} / \mathrm{d}$ C18:2 trans-10, cis-12 (CP12 CLA $_{\text {). }}$.

The experiment was conducted with a $4 \times 4$ Latin square design over 4 periods of 3 wk each (2 wk for adaption, the third week for sample collection). Each group, therefore, received the CP15 or CP12 TMR for 6 consecutive weeks, changing the CLA supplementation 
without simultaneously changing the $\mathrm{CP}$ content of the diet, and, similarly, changing the $\mathrm{CP}$ content without simultaneously changing the rpCLA supplementation (Schiavon et al., 2015).

\section{Cheese Making and Composition}

On d 2 and 4 of the third week of each experimental period, morning milk samples $(1,200 \mathrm{~mL})$ were taken from all the cows, pooled by group, and then poured into 2 laboratory cheesemaking vats (10-L capacity; Pierre Guerin Technologies, Mauze, France).

Details of the cheesemaking process are given in Schiavon et al. (2016). Cheeses were manufactured simultaneously across the 4 experimental treatments in 2 sessions per period: 4 groups $\times 4$ periods $\times 2$ sessions, for a total of 32 cheesemakings. Each curd obtained was then portioned into 3 cheese molds and pressed, giving a total of 96 wheels ( 4 groups $\times 4$ periods $\times 2$ sessions $\times 3$ wheels). The cheeses were ripened for 90 $\mathrm{d}$ at $15^{\circ} \mathrm{C}$ and $85 \%$ relative humidity (initial weight of $\sim 500 \mathrm{~g} /$ wheel), after which the chemical composition was determined with a Food Scan analyzer (Foss Electric, Hillerød, Denmark). The pH of each cheese was measured at $20^{\circ} \mathrm{C}$ by inserting a Crison Basic 20 electrode (Crison, Barcelona, Spain) into it. We then took a cylindrical sample of paste, $1.1 \mathrm{~cm}$ in diameter and about $3.5 \mathrm{~cm}$ high, from the center of one cheese per cheesemaking (32 core samples weighing about 3 g each), and kept them at $-80^{\circ} \mathrm{C}$ until VOC analysis. Descriptive statistics of the cheese composition are presented in Table 1.

\section{Solid-Phase Microextraction and GC-MS Analyses of Cheese VOC}

The VOC in the cheese samples were analyzed according to the method reported by Bergamaschi et al. (2015a). Briefly, the cheese samples were thawed at room temperature in glass vials $(20 \mathrm{~mL}$; Supelco, Bellefonte, PA), and then gently crushed with a spatula; after capping with a polytetrafluoroethylene-silicone septum (Supelco), they were equilibrated at $40^{\circ} \mathrm{C}$ for 30 min. A solid-phase microextraction (SPME) fusedsilica fiber coated with $50 / 30 \mu \mathrm{m}$ divinylbenzene/ carboxen/polydimethylsiloxane (DBV/CAR/PDMS; Supelco) was exposed for $30 \mathrm{~min}$ to the headspace of the sample vials, which were maintained at $40^{\circ} \mathrm{C}$. The volatile compounds were absorbed by the SPME fiber and desorbed at $250^{\circ} \mathrm{C}$ in the injector port of a GC (Clarus 500, PerkinElmer, Norwalk, CT) interfaced with a mass detector operating in electron ionization mode (internal ionization source; $70 \mathrm{eV}$ ) with a scan range from $m / z 33$ to 300 . The SPME analysis and in-
Table 1. Descriptive statistics of Holstein cow traits and composition of milk samples and ripened cheeses

\begin{tabular}{lcc}
\hline Trait & Mean & SD \\
\hline Holstein cows $(\mathrm{n}=20)$ & 2.00 & \\
Parity, no. & 148 & 64 \\
Initial DIM, d & 647 & 22.0 \\
BW, kg & 2.92 & 0.29 \\
BCS & 20.8 & 2.0 \\
DMI, kg/d & 28.1 & 2.7 \\
Milk yield, kg/d & & \\
Milk composition $(\mathrm{n}=32)$ & 3.34 & 0.89 \\
Fat, \% & 3.45 & 0.46 \\
Protein, \% & 4.72 & 0.21 \\
Lactose, \% & & \\
Cheese composition $(\mathrm{n}=32)$ & 5.32 & 0.22 \\
pH & 43.7 & 5.4 \\
Fat, \% & 25.9 & 5.8 \\
Protein, \% & 1.82 & 0.63 \\
Fat:protein & 1.97 & 0.12 \\
Salt, \% & & \\
\hline
\end{tabular}

jection were automated by means of an auto-sampling system (CTC combiPAL, CTC Analysis AG, Zwingen, Switzerland). Separation of VOC was carried out on an HP-Innowax fused-silica capillary column $(30 \mathrm{~m}, 0.32$ $\mathrm{mm}$ i.d., 0.5- $\mu \mathrm{m}$ film thickness; Agilent Technologies, Palo Alto, CA), and the data were expressed as a fraction of the total chromatography area. The separation conditions are described in a previous study (Aprea et al., 2016). We identified 48 individual VOC, grouped into 10 chemical classes.

\section{Statistical Analysis}

The concentrations of individual VOC and the sum of each VOC chemical family group had positively skewed distributions; the data were transformed to obtain a Gaussian-like data distribution, in agreement with Bergamaschi et al. (2015a) and Bergamaschi and Bittante (2018). The content of each VOC plus 1 was expressed as a natural logarithm, $\ln (x+1)$, where $x$ is the amount of the VOC (quantitative data set). In a second (qualitative) data set, the proportion of each VOC was multiplied by $10^{6}$ plus 1 and then transformed as a natural logarithm, $\ln \left[\left(x / \Sigma x \times 10^{6}\right)+1\right]$, where $x$ is the VOC content and $\Sigma x$ the sum of VOC per cheese. Outlier detection was based on the residuals of the model for all the VOC before any statistical analysis. Data with residuals $>3$ residual standard deviations in absolute value were considered outliers and removed. The 48 individual VOC, the 10 VOC chemical family groups, and the sum of all VOC in each data set were considered dependent variables and were analyzed (117 univariate statistical analyses) using the SAS mixed model procedure (SAS Institute Inc., Cary, NC) with the following model: 


$$
\begin{gathered}
\mathrm{y}_{i j k l m}=\mu+\mathrm{P}_{i}+\mathrm{G}_{j}+\mathrm{D}_{k}+\mathrm{C}_{l}+\mathrm{P} \times \mathrm{C}_{i l} \\
+\mathrm{D} \times \mathrm{P}_{k i}+\mathrm{D} \times \mathrm{P} \times \mathrm{C}_{k i l}+\mathrm{e}_{i j k l m},
\end{gathered}
$$

where $\mathrm{y}_{i j k l m}$ is the observed variable (the sum of all VOC, the 48 individual VOC, and the 10 chemical families for each data set); $\mu$ is the overall mean; $\mathrm{P}_{i}$ is the fixed effect of the $i$ th period ( $i=1$ to 4$) ; \mathrm{G}_{j}$ is the random effect of the $j$ th group of cows $(j=1, \ldots, 4)$; $\mathrm{D}_{k}$ is the fixed effect of the $k$ th dietary treatment $(k=$ $1, \ldots, 4) ; \mathrm{C}_{l}$ is the fixed effect of the $l$ th cheesemaking session within each period $(l=1,2) ; \mathrm{P} \times \mathrm{C}_{i l}$ is the fixed effect of the $i$ th interaction between period and cheesemaking session $(i l=1, \ldots, 8) ; \mathrm{D} \times \mathrm{P}_{k i}$ is the random effect of the kith interaction between dietary treatment and period $(k i=1, \ldots, 16) ; \mathrm{D} \times \mathrm{P} \times \mathrm{C}_{k i l}$ is the random effect of the interaction between dietary treatment, period, and cheesemaking session $(k i l=1$, $\ldots, 32)$; and $\mathrm{e}_{i j k l m}$ is the random residual term $\sim N\left(0, \sigma^{2}\right)$.

As the correlation analysis between all these dependent variables yielded 6,786 correlation coefficients, to study the relationships among the cheese VOC and reduce the size of the 2 data sets, we applied a multivariate data treatment (factor analysis) to identify a few new independent latent explanatory factors (LEF) using the "psych" packages in R (www.r-project.org). As the number of traits included in the multivariate analysis cannot exceed the number of observations (32 cheeses), we limited the number of VOC to be included in the factor analyses to those in each data set showing an effect of dietary CP restriction and (or) CLA addition and (or) their interaction at a probability of least $P<0.10$ during the preliminary univariate mixed model analyses (17 VOC from the quantitative data set and 29 from the qualitative data set).

All of the Pearson correlations and residual correlations (using the residuals obtained from the previously described univariate mixed model) were calculated from each of these 2 reduced cheese VOC data sets.

The multivariate factor analysis yielded a set of 5 LEF for each data set, which were then analyzed using the same mixed model as that used for individual VOC and their chemical families.

\section{RESULTS}

We identified a total of 48 individual VOC in the cheeses (see Supplemental Table S1; https://doi.org/10 .3168/jds.2019-16495) belonging to 10 chemical classes as follows: 11 alcohols from $\mathrm{C}_{4}$ to $\mathrm{C}_{9} ; 8$ ketones from $\mathrm{C}_{3}$ to $\mathrm{C}_{9} ; 8$ esters from $\mathrm{C}_{3}$ to $\mathrm{C}_{10} ; 7$ acids from $\mathrm{C}_{2}$ to $\mathrm{C}_{10}$; 4 aldehydes from $\mathrm{C}_{5}$ to $\mathrm{C}_{9} ; 4$ sulfurs from $\mathrm{C}_{1}$ to $\mathrm{C}_{2} ; 2$ lactones, $\mathrm{C}_{4}$ and $\mathrm{C}_{8} ; 2$ phenolics, $\mathrm{C}_{6}$ and $\mathrm{C}_{7} ; 1$ monoterpene; and 1 hydrocarbon. The most abundant VOC identified from SPME were fatty acids, particularly the odd ones (hexanoic, butanoic, octanoic, acetic, and decanoic acids), followed by esters, alcohols, ketones and aldehydes; the least abundant VOC were lactones, hydrocarbon, sulfurs, and phenolic substances.

\section{Effects of Dietary Treatments on Chemical Families and Individual VOC}

The results of the mixed model on VOC chemical families are shown in Table 2, and those on the individual VOC in Supplemental Tables S1 and S2 (https: /doi.org/10.3168/jds.2019-16495), which report the effects of dietary CP, CLA addition, and their interaction on, respectively, the quantitative and qualitative VOC profiles.

From the quantitative point of view, we found that reducing $\mathrm{CP}$ in the diet depressed the volatilization of aldehydes (Table 2), particularly 3-methylbutanal and benzaldehyde (Supplemental Table S1), as well as other individual VOC: 1 ketone (3-hydroxy-butan-2-one), 1 organic acid (heptanoic acid), and 1 phenolic substance (4-methylphenol). In contrast, it increased the volatilization of 1 ester (isopropyl isobutanoate).

Acid and ester VOC families and the sum of all VOC were dramatically increased by supplementing the diets of lactating cows with CLA (Table 2). The volatilization of all odd fatty acids, except acetate (Supplemental Table S1), and the esters ethyl butanoate, ethyl hexanoate, ethyl octanoate, and $\delta$-octalactone were, in particular, increased.

An interaction between the effects of dietary CP level and CLA addition came close to statistical significance $(P=0.06$; Table 2$)$ for the VOC family of alcohols and was significant for 2-methyl-butan-1-ol (Supplementary Table S1; https://doi.org/10.3168/jds.2019-16495); these were depressed in cheeses made from the milk of cows fed the control CP diet with CLA addition and slightly increased with the low-CP diet. The opposite pattern was observed in 1 volatile ketone (propan-2-one, acetone) and a lactone ( $\gamma$-butyrolactone).

When the VOC were expressed as a proportion of their total quantity (qualitative data set), the results were very different from the quantitative data set for both the VOC chemical families (Table 2) and the individual VOC (Supplemental Table S2; https://doi.org/ 10.3168/jds.2019-16495). In fact, the reduction in CP induced a slight decrease in the proportion of the volatile organic acid chemical family and of an individual ketone (3-hydroxy-butan-2-one), and an increase in the proportions of esters (ethyl butanoate, isopropyl isobutanoate, 3-methylbutyl butanoate, ethyl hexanoate, and ethyl octanoate), and the monoterpene limonene. 
The addition of CLA to the diet depressed the proportions in cheese of the families of ketones (propan2-one, acetone, 3-hydroxy-butan-2-one, pentan-21, hexan-2-one, heptan-3-one) and phenolics (phenol and 4-methylphenol), as well as heptanoic acid, limonene, methanethiol, and dimethyl sulfone.

Determining the volatile emission of alcohols from ripened cheese was more complex due to the contemporaneous effect of both dietary treatments and their interaction. Adding CLA to the feed of cows on the control TMR reduced the amount of alcohols in the cheeses, but there was no similar reduction when CLA was added to the low-CP diets (Table 2). The interaction was significant for only 4 of the 11 alcohols analyzed in the headspace of the cheeses, even though the CP15 CLA cheeses were those with the lowest proportions of each of these alcohols (Supplemental Table S2; https: //doi.org/10.3168/jds.2019-16495). Two aldehydes (hexanal and benzaldehyde), 1 ketone (heptan-3-one), and 1 lactone ( $\delta$-octalactone) exhibited a similar trend (Supplemental Table S2).

\section{Correlations Between Individual VOC}

We performed correlation and multivariate factor analyses on the $17 \mathrm{VOC}$ from the quantitative data set and the 29 VOC from the qualitative data set that exhibited an effect of dietary CP, CLA addition, or their interaction at a level of significance of at least $P$ $<0.10$. The results of the 272 correlation coefficients obtained from the quantitative data are summarized in the heatmap in Figure 1.

First, it is clear that, with few exceptions, there was little difference between the Pearson correlations (above the diagonal) and the residuals (below the diagonal), which means that the factors included in the mixed model (experimental diet, cow group, period, cheesemaking session, and some interactions) had little direct effect on the correlations of the quantitative VOC data.

Second, we observed that most correlations in the quantitative VOC profile were positive, some were almost null, and only a few were negative. The only VOC with concentrations negatively correlated with or al-

Table 2. Volatile organic compounds (VOC) profile of ripened cheese: effects of dietary CP shortage and CLA addition on the concentration (quantitative) and proportion (qualitative) of VOC according to their chemical family

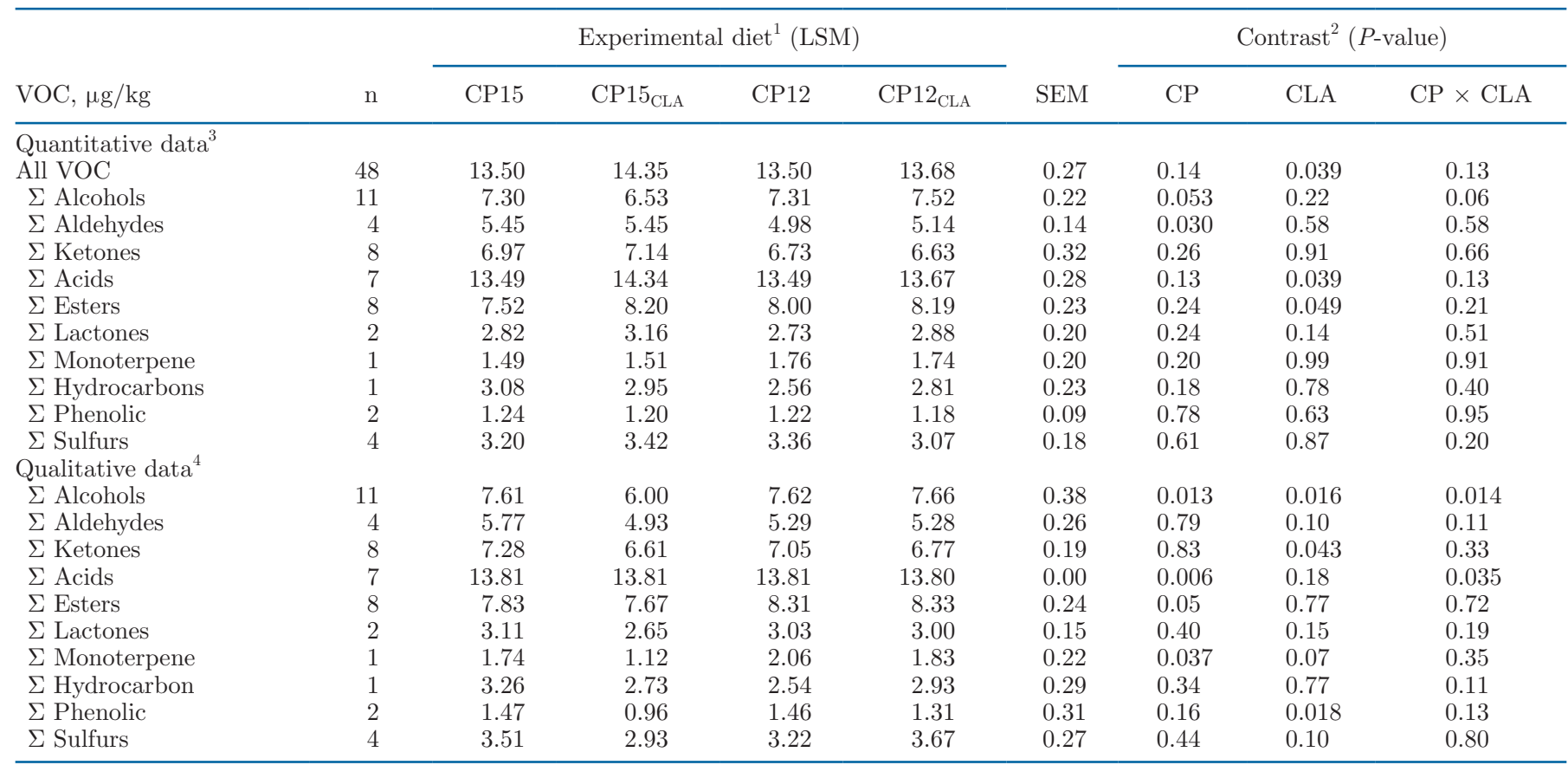

${ }^{1} \mathrm{CP} 15=$ cows fed a control TMR with $15.0 \% \mathrm{CP}$; CP15 $\mathrm{CLA}=$ cows fed CP15 and a supplement with rumen-protected CLA (7.9 g/d C18:2 cis9,trans-11 and $7.7 \mathrm{~g} / \mathrm{d}$ C18:2 trans-10,cis-12); CP12 = cows fed a low-protein TMR with $12.3 \% \mathrm{CP}$; CP12 $\mathrm{CLA}=$ cows fed CP12 and the CLA supplement.

${ }^{2}$ Orthogonal contrasts: $\mathrm{CP}=\left(\mathrm{CP} 15+\mathrm{CP} 15_{\mathrm{CLA}}\right)$ vs. $\left(\mathrm{CP} 12+\mathrm{CP} 12_{\mathrm{CLA}}\right) ; \mathrm{CLA}=(\mathrm{CP} 15+\mathrm{CP} 12)$ vs. $\left(\mathrm{CP} 15_{\mathrm{CLA}}+\mathrm{CP} 12_{\mathrm{CLA}}\right) ; \mathrm{CP} \times \mathrm{CLA}=$ $\left(\mathrm{CP} 15+\mathrm{CP} 12_{\mathrm{CLA}}\right)$ vs. $\left(\mathrm{CP} 12+\mathrm{CP} 15_{\mathrm{CLA}}\right)$.

${ }^{3}$ Expressed as $\ln (x+1)$, where $x$ is the amount of the VOC.

${ }^{4}$ Expressed as $\ln \left[\left(x / \Sigma x \times 10^{6}\right)+1\right]$, where $x$ is the VOC content and $\Sigma x$ the sum of VOC per cheese. 
most independent of all the other VOC were isopropyl isobutanoate and, to a lesser extent, 3-hydroxy-butan2-one.

The highest positive correlations were those between all of the volatilized fatty acids, including butanoic, hexanoic, heptanoic, octanoic, and decanoic acids, with an average correlation of 0.91 . The volatilized esters were also positively correlated with each other, although to a more variable extent than the acids, with the evident exception of isopropyl isobutanoate. The acids and esters were also correlated with each other (average 0.66). The correlations among the concentrations of the other VOC were more variable.
The results of the 812 correlation coefficients obtained from the qualitative VOC profile are summarized in the heatmap in Figure 2. In this case, the pattern of the Pearson correlations was very different from that of the residual correlations. The Pearson correlations were not as strong as in the quantitative profile and they were more equally distributed between positive and negative, as expected for proportions whose sum is a constant. The qualitative residual correlations, in contrast, were more often high and positive, as in the quantitative profile, the more obvious exceptions (with negative and null correlations with other VOC) being an alcohol (heptan-2-ol) and an acid (heptanoic acid), both with

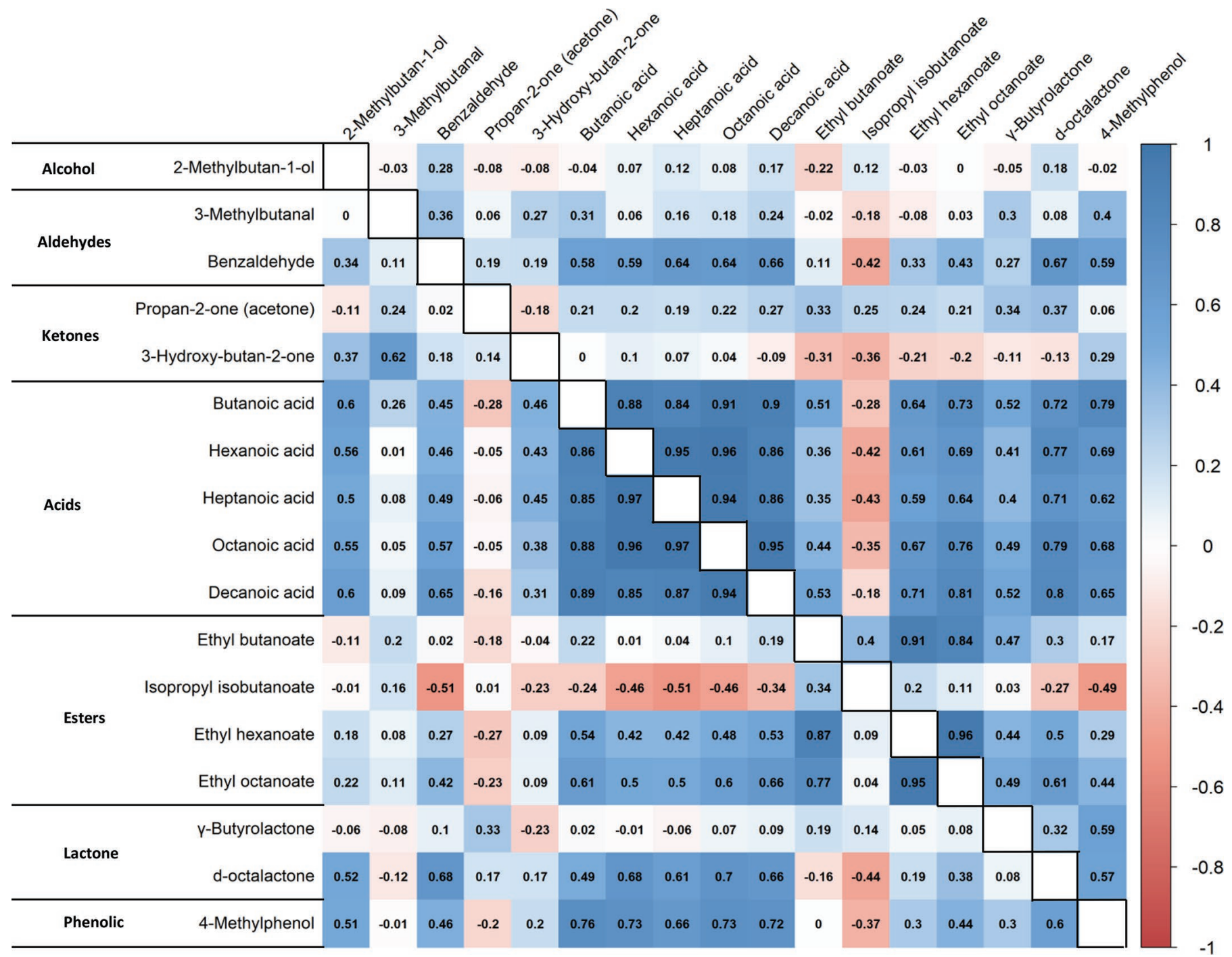

Figure 1. Quantitative volatile organic compound (VOC) profile of ripened cheese: Pearson correlations above the diagonal and mixed model residual correlations below the diagonal among concentrations of individual VOC are shown (only VOC having statistical significance of at least $P<0.10$ for the effect of dietary CP, CLA addition, or their interaction were included in the heatmap). 


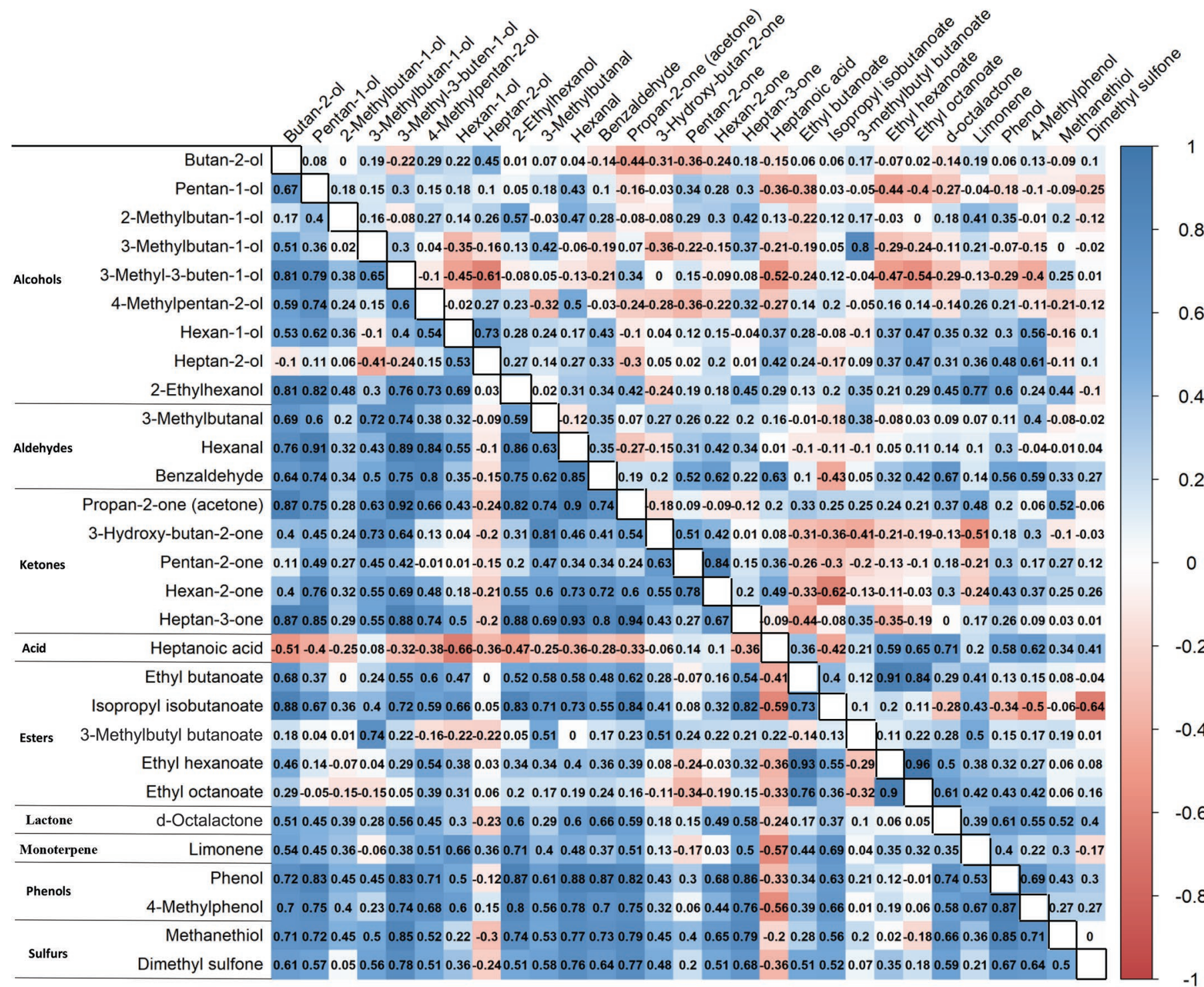

Figure 2. Qualitative volatile organic compound (VOC) profile of ripened cheese: Pearson correlations above the diagonal and mixed model residual correlations below the diagonal among the proportion of individual VOC on their sum are shown (only VOC having statistical significance of at least $P<0.10$ for the effect of dietary CP, CLA addition, or their interaction were included in the heatmap).

a chain of 7 carbon atoms. It is worth noting that the pattern of correlations was relatively unaffected by the VOC chemical family, but instead depended more on individual factors.

\section{New LEF Associated with Ripened Cheese VOC Profiles}

Many compounds contribute to the flavor and odor of cheese, and the chemical family that these VOC belong to was shown to play a role in explaining overall variability only when they were expressed as concentrations, not when expressed as a proportion of the total.
We therefore used a multivariate data treatment (factor analysis) to convert the multiple individual responses of individual VOC into a small number of independent variables. All the loading coefficients relating to the first $5 \mathrm{LEF}$ for the individual VOC are shown in Table 3.

Regarding the quantitative VOC profile, the first 5 LEF together explained $79 \%$ of the total variance in the concentrations of the 19 individual VOC. The first factor, LEF-1, was very important because it explained about half of the explained variance ( $43 \%$ of the total) and was loaded by about half of the VOC analyzed: the sum of all VOC and 9 individual VOC, the most 
Table 3. Results of factor analysis of volatile organic compounds (VOC) profile of ripened cheese: proposed name, loading and communality of the first 5 latent explanatory factors (LEF) of the quantitative and qualitative data sets (only VOC having at least $P<0.10$ significance of the effect of dietary CP, CLA addition, or CP $\times$ CLA were included in the multivariate analysis)

\begin{tabular}{|c|c|c|c|c|c|c|c|}
\hline Item & Group & LEF-1 & LEF-2 & LEF-3 & LEF-4 & LEF-5 & Communality $^{1}$ \\
\hline \multicolumn{8}{|l|}{ Quantitative data set } \\
\hline 2-Methylbutan-1-ol & Alcohol & 0.10 & -0.02 & -0.05 & 0.90 & -0.04 & 0.83 \\
\hline 3-Methylbutanal & Aldehyde & 0.09 & -0.12 & 0.55 & 0.01 & 0.04 & 0.33 \\
\hline Benzaldehyde & Aldehyde & 0.63 & -0.08 & 0.30 & 0.26 & 0.09 & 0.56 \\
\hline Hexanoic acid & Acid & 0.97 & 0.04 & 0.11 & -0.03 & 0.03 & 0.90 \\
\hline Heptanoic acid & Acid & 0.95 & 0.03 & 0.07 & 0.02 & 0.04 & 0.90 \\
\hline Octanoic acid & Acid & 0.96 & 0.14 & 0.17 & 0.00 & 0.03 & 0.90 \\
\hline Decanoic acid & Acid & 0.87 & 0.29 & 0.24 & 0.12 & 0.07 & 0.90 \\
\hline Ethyl butanoate & Ester & 0.32 & 0.87 & 0.09 & -0.25 & 0.08 & 0.90 \\
\hline Isopropyl isobutanoate & Ester & -0.45 & 0.67 & -0.12 & 0.18 & 0.22 & 0.75 \\
\hline All VOC & & 0.95 & 0.13 & 0.21 & -0.07 & 0.01 & 0.90 \\
\hline Explained variance, $\%$ & & 43.0 & 15.0 & 9.00 & 6.00 & 6.00 & 79.0 \\
\hline \multirow[t]{2}{*}{ Eigen value } & & 0.51 & 0.15 & 0.08 & 0.07 & 0.05 & 0.86 \\
\hline & & Base aroma & Ethyl esters & Butan- & Heptan- & Pentan- & \\
\hline \multicolumn{8}{|l|}{ Qualitative data set } \\
\hline \multicolumn{8}{|l|}{ Proposed name } \\
\hline Butan-2-ol & Alcohol & 0.17 & 0.00 & 0.23 & 0.53 & -0.32 & 0.46 \\
\hline Pentan-1-ol & Alcohol & 0.88 & 0.15 & 0.19 & 0.24 & 0.10 & 0.90 \\
\hline 2-Methylbutan-1-ol & Alcohol & 0.63 & 0.13 & 0.28 & 0.29 & 0.26 & 0.64 \\
\hline 3-Methylbutan-1-ol & Alcohol & 0.43 & 0.01 & 0.85 & 0.01 & -0.02 & 0.90 \\
\hline 3-Methyl-3-buten-1-ol & Alcohol & 0.93 & 0.18 & 0.20 & -0.08 & 0.00 & 0.90 \\
\hline 4-Methylpentan-2-ol & Alcohol & 0.71 & 0.39 & 0.18 & 0.32 & -0.12 & 0.81 \\
\hline Hexan-2-one & Ketone & 0.82 & -0.07 & 0.03 & 0.13 & 0.48 & 0.90 \\
\hline Heptan-3-one & Ketone & 0.88 & 0.13 & 0.30 & 0.14 & 0.08 & 0.90 \\
\hline Heptanoic acid & Acid & 0.00 & -0.15 & -0.07 & -0.23 & 0.59 & 0.43 \\
\hline Ethyl butanoate & Ester & 0.34 & 0.87 & 0.06 & -0.03 & -0.17 & 0.90 \\
\hline Isopropyl isobutanoate & Ester & 0.72 & 0.56 & 0.22 & 0.04 & -0.09 & 0.88 \\
\hline 3-Methylbutyl butanoate & Ester & 0.11 & 0.02 & 0.94 & -0.03 & -0.14 & 0.90 \\
\hline Ethyl hexanoate & Ester & 0.18 & 0.96 & -0.02 & 0.01 & -0.04 & 0.90 \\
\hline Ethyl octanoate & Ester & -0.10 & 0.93 & 0.02 & 0.14 & -0.07 & 0.90 \\
\hline$\delta$-Octalactone & Lactone & 0.70 & 0.15 & 0.15 & -0.04 & -0.03 & 0.53 \\
\hline Limonene & Terpene & 0.49 & 0.37 & 0.41 & 0.20 & -0.28 & 0.66 \\
\hline Phenol & Phenol & 0.86 & 0.06 & 0.18 & 0.08 & -0.07 & 0.79 \\
\hline 4-Methylphenol & Phenol & 0.79 & -0.10 & -0.01 & 0.28 & -0.16 & 0.74 \\
\hline Methanethiol & Sulfur & 0.91 & 0.10 & 0.15 & -0.13 & -0.06 & 0.89 \\
\hline Dimethyl sulfone & Sulfur & 0.73 & -0.01 & 0.09 & 0.01 & 0.05 & 0.54 \\
\hline Explained variance, $\%$ & & 44.0 & 13.0 & 9.00 & 7.00 & 6.00 & 78.0 \\
\hline Eigen value & & 0.51 & 0.12 & 0.08 & 0.07 & 0.04 & 0.82 \\
\hline
\end{tabular}

${ }^{1}$ The fraction of VOC variance explained by the LEF. 
Table 4. Volatile organic compounds (VOC) profile of ripened cheese: effects of dietary CP shortage, CLA addition, and CP $\times$ CLA on the latent explanatory factors (LEF) of quantitative and qualitative VOC profiles

\begin{tabular}{|c|c|c|c|c|c|c|c|c|c|}
\hline \multirow[b]{2}{*}{ Factor } & \multirow[b]{2}{*}{ LEF name } & \multicolumn{4}{|c|}{ Experimental $\operatorname{diet}^{1}(\mathrm{LSM})$} & \multirow[b]{2}{*}{ SEM } & \multicolumn{3}{|c|}{ Contrast $^{2}(P$-value $)$} \\
\hline & & $\mathrm{CP} 15$ & $\mathrm{CP} 15_{\mathrm{CLA}}$ & $\mathrm{CP} 12$ & $\mathrm{CP} 12_{\mathrm{CLA}}$ & & $\mathrm{CP}$ & CLA & $\mathrm{CP} \times \mathrm{CLA}$ \\
\hline \multicolumn{10}{|c|}{ Quantitative data ${ }^{3}$} \\
\hline LEF-1 & Intensity & -0.22 & 0.67 & -0.36 & -0.10 & 0.35 & 0.16 & 0.08 & 0.30 \\
\hline LEF-2 & Ethyl esters & -0.62 & -0.11 & 0.23 & 0.50 & 0.31 & 0.045 & 0.22 & 0.70 \\
\hline LEF-3 & Phenol & 0.31 & 0.20 & -0.08 & -0.43 & 0.33 & 0.11 & 0.43 & 0.68 \\
\hline LEF-4 & Butanol & 0.42 & -0.84 & 0.08 & 0.34 & 0.29 & 0.13 & 0.09 & 0.020 \\
\hline LEF-1 & Base aroma & 0.44 & -0.57 & 0.25 & -0.11 & 0.34 & 0.64 & 0.044 & 0.28 \\
\hline LEF-2 & Ethyl esters & -0.38 & -0.41 & 0.28 & 0.51 & 0.37 & 0.06 & 0.79 & 0.72 \\
\hline LEF-3 & Butan- & -0.11 & -0.46 & 0.14 & 0.42 & 0.19 & 0.024 & 0.86 & 0.15 \\
\hline LEF-4 & Heptan- & 0.42 & -0.69 & 0.15 & 0.12 & 0.30 & 0.39 & 0.09 & 0.11 \\
\hline LEF-5 & Pentan- & 0.42 & -0.32 & -0.02 & -0.08 & 0.33 & 0.74 & 0.20 & 0.26 \\
\hline
\end{tabular}

${ }^{1} \mathrm{CP} 15=$ cows fed a control TMR with $15.0 \% \mathrm{CP} ; \mathrm{CP} 15_{\mathrm{CLA}}=$ cows fed CP15 and a supplement with rumen-protected CLA (7.9 g/d C18:2 cis9,trans-11 and $7.7 \mathrm{~g} / \mathrm{d}$ C18:2 trans-10,cis-12); CP12 = cows fed a low-protein TMR with $12.3 \% \mathrm{CP}$; CP12 $\mathrm{CLA}=$ cows fed CP12 and the CLA supplement.

${ }^{2}$ Orthogonal contrasts: $\mathrm{CP}=\left(\mathrm{CP} 15+\mathrm{CP} 15_{\mathrm{CLA}}\right)$ vs. $\left(\mathrm{CP} 12+\mathrm{CP} 12_{\mathrm{CLA}}\right) ; \mathrm{CLA}=(\mathrm{CP} 15+\mathrm{CP} 12)$ vs. $\left(\mathrm{CP} 15_{\mathrm{CLA}}+\mathrm{CP} 12_{\mathrm{CLA}}\right) ; \mathrm{CP} \times \mathrm{CLA}=$ $\left(\mathrm{CP} 15+\mathrm{CP} 12_{\mathrm{CLA}}\right)$ vs. $\left(\mathrm{CP} 12+\mathrm{CP} 15_{\mathrm{CLA}}\right)$.

${ }^{3}$ Expressed as $\ln (x+1)$, where $x$ is the amount of the VOC.

${ }^{4}$ Expressed as $\ln \left[\left(x / \Sigma x \times 10^{6}\right)+1\right]$, where $x$ is the VOC content and $\Sigma x$ the sum of VOC per cheese.

important being the odd fatty acids from $\mathrm{C} 4$ to $\mathrm{C} 10$ (loading coefficients of 0.85 to 0.97 ). One aldehyde (benzaldehyde), 1 ester (ethyl octanoate), 1 lactone ( $\delta$-octalactone), and 1 phenolic compound (4-methylphenol) were also included in LEF-1, but with lower loading coefficients (0.62 to 0.78 ). As the 5 organic acids included in LEF-1 were, along with acetate, quantitatively the most important of all the volatile compounds of ripened cheese, LEF-1 was named "intensity" of the cheese VOC profile.

Factor LEF-2 explained 15\% of total variance and was mainly loaded by the 4 esters: ethyl butanoate, isopropyl isobutanoate, ethyl hexanoate, and ethyl octanoate, and was therefore named "ethyl esters." The following $3 \mathrm{LEF}$ were largely one-trait factors: LEF-3 ( $9 \%$ of total variance, named "phenol") was loaded by phenolic 4-methylphenol, LEF-4 (6\% of total variance, named "butanol") mainly by alcohol 2-methylbutan1-ol, and LEF-5 (6\% of total variance, named "acetone") by ketone propan-2-one.

With respect to the qualitative data, the first $5 \mathrm{LEF}$ together explained $78 \%$ of the total variance in the proportions of the individual 29 VOC included in the analysis. Here, too, the first LEF was very important, explaining more than half of the explained variance (44\% of the total). As previously seen, organic acids were quantitatively the most important VOC of ripened cheese, and consequently characterized the quantitative LEF-1 "intensity." After being expressed as proportions of the sum of all VOC in the qualitative data set, the acids, with the exception of heptanoic acid, were ex- cluded, because their proportions were not affected by dietary CP restriction, CLA addition, or their interaction. The qualitative LEF-1 was, therefore, based on the proportions of $17 \mathrm{VOC}$ (Table 3 ) belonging to other chemical families ( 5 alcohols, 2 aldehydes, 4 ketones, 1 ester, 1 lactone, 2 phenols, and 2 sulfur compounds), and was named "base aroma" of cheese.

The second qualitative LEF was based on the same ethyl esters as the corresponding quantitative LEF-2, so was again named "ethyl esters" and represented $13 \%$ of all variance. Factor LEF-3 represented 9\% of total variance and loaded 2 compounds with a chain of 4 carbons: 1 alcohol (3-methylbutan-1-ol) and 1 ester (3-methylbutyl butanoate), and was named "butan-". Finally, qualitative LEF-4 and LEF-5 were one-trait factors, based, respectively, on the alcohol heptan2-ol ("heptan-", $7 \%$ of total variance) and the ketone pentan-2-one ("pentan-", $6 \%$ of total variance).

\section{Effects of Dietary Treatments on LEF of Cheese VOC}

Results of the mixed model applied to the $10 \mathrm{LEF}$ obtained from the quantitative and qualitative VOC data sets are summarized in Table 4. As can be seen, reducing $\mathrm{CP}$ in the diets of dairy cows increased the LEF-2 "ethyl esters" in both the quantitative (significantly) and qualitative (almost significantly) data sets, as well as the qualitative LEF-3 "butan-".

Supplementing the diets of lactating cows with rpCLA decreased the most important qualitative LEF: LEF-1 ("base aroma"). It is also worth noting that 
there was an interaction of dietary CP level and CLA addition in the case of quantitative LEF-4 ("butanol"), which was highly reduced in cheeses obtained from the milk of cows fed the CP15 $15_{\text {CLA }}$ diet compared with the other 3 experimental diets.

\section{DISCUSSION}

In a previous study (Bergamaschi and Bittante, 2018), we monitored the fate of $49 \mathrm{VOC}$ (analyzed using the same procedure as here) during each step of the cheesemaking process in 11 dairy products and by-products, and found that the total quantities of VOC can increase more than 10-fold in 6 mo of cheese ripening compared with quantities in the fresh curd. The increases differed greatly in different VOC and were particularly substantial for some alcohols (100-fold), aldehydes (20-fold), fatty acids (20-fold), and ketones (60-fold). This means that the final cheese aroma profile depends on curd composition and, particularly, on the native and microbiological enzyme activities that take place during ripening. Nevertheless, in studies carried out on 1,000 model cheeses made from milk produced on 85 farms but all manufactured in the same laboratory and ripened in the same environment, we found that the VOC profiles and final sensory profiles of the ripened cheeses were affected by the dairy system in which the cows were reared (Bergamaschi et al., 2015b; Cipolat-Gotet et al., 2018), as well as by the cow's genetic background (Bergamaschi et al., 2016; Pegolo et al., 2018). The sensory profile of cheese is known to be the main factor determining consumer preference (Drake, 2007; Bittante et al., 2011a,b). The dairy systems examined in the previous study differed not only in animal housing (tied or loose) and milking systems, but also in feeding regimen (e.g., forage/concentrate ratio, TMR, presence of silages). The differences in flavor profile observed in previous studies for different dairy systems could be also related to diet characteristics, included the level of CP and the fatty acid profile of feedstuffs (CipolatGotet et al., 2018; Schiavon et al., 2018).

We are unaware of any previous study directly investigating the effects of dietary CP level, CLA addition, or their interaction on the flavor profile of ripened cheese. We will discuss the results of our study in terms of known metabolic pathways from diet to rumen metabolism, udder synthesis, and modification of the cheese during ripening.

\section{Effects of CP Shortage on the Flavor Profile of Ripened Cheese}

Dietary CP together with feed energy strongly affect rumen metabolism, AA absorption, and mam- mary protein synthesis (Schiavon et al., 2012). Milk and cheese proteins are, in turn, important precursors of several cheese VOC. It worth noting that reducing the CP content of the TMR in this experiment (Schiavon et al., 2015) reduced the cows' daily DMI $(-7.7 \% ; P=0.09)$ and daily ECM yield $(-6.8 \% ; P$ $=0.01)$ but not their efficiency $(-0.4 \%)$. Regarding milk quality, dietary $\mathrm{CP}$ reduction did not affect milk fat percentage or daily fat production, but decreased milk protein percentage $(-4.7 \% ; P=0.03)$ and daily protein production $(-9.4 \% ; P<0.01)$, and, consequently, lowered the protein-to-fat ratio in the cheese. However, this cannot be the main factor responsible for the observed effects of dietary $\mathrm{CP}$ reduction on the ripened cheese VOC profile, which tended to be much more intense.

During ripening, proteolysis degrades cheese proteins to multiple free AA (Bertuzzi et al., 2018), and AA in turn form some VOC, including phenol, sulfurs, and aldehydes, which can give rise to some acids and alcohols (McSweeney and Sousa, 2000). The alcohols and fatty acids then form esters by enzymatic and chemical reactions such as esterification (Curioni and Bosset, 2002; Liu et al., 2004). Our analysis of the data with the mixed model showed that the reduction in dietary $\mathrm{CP}$ decreased the quantities of the aldehyde VOC chemical family (Table 2), and qualitatively increased the proportions of esters (confirmed by the increase in LEF-2 "ethyl esters") and limonene (monoterpene).

Ester are important VOC for cheese flavor but their initial content in milk and curd is more important than the biochemical modifications they undergo during ripening (Bergamaschi and Bittante, 2018); the differences observed in ripened cheeses might derive in part from differences in the initial content of esters in milk more than on different ripening processes (Liu et al., 2004). The cheese esters that increased with dietary $\mathrm{CP}$ reduction included ethyl butanoate, isopropyl isobutanoate, ethyl hexanoate, ethyl octanoate, and 3-methylbutyl butanoate, which contribute to sweet, fruity, floral notes (Qian and Reineccius, 2002; Thomsen et al., 2012). They also had generally positive correlations with each other (Figure 1). Ethyl butanoate and ethyl hexanoate are the most important volatile ester compounds found in cheese (Engels et al., 1997). The former is mainly produced by esterification of ethanol and butyric acid by lactobacilli, pediococci, and leuconostocs (lactic acid bacteria) and propionibacteria (Liu et al., 1998). Ethyl hexanoate and ethyl octanoate derive mainly from fatty acids reacting with the alcohol group (Marilley and Casey, 2004).

Monoterpenes usually come from plants and contribute to the fresh, herbaceous odor of cheese (Vialloninsta et al., 2000; Carpino et al., 2004). The increase 
observed in our study could be affected by rumen microflora metabolism (Bergamaschi et al., 2015a), which is known to be affected by low-CP diets and to affect the final aroma of cheese (Smit et al., 2005).

The changes in VOC profile observed here as a consequence of dietary $\mathrm{CP}$ shortage are expected to increase the floral notes of ripened cheese (e.g., fresh, herbaceous, sweet, fruit), which are generally considered positively by the dairy industry and consumers (Agabriel et al., 2004). Some authors evaluated the odor characteristics of many individual VOC of different cheeses using gas-chromatography/olfactometry (Curioni and Bosset, 2002; Qian and Reineccius, 2002; Frank et al., 2004; Thomsen et al., 2012). From those studies, it can be seen that most VOC analyzed in this study were present in concentrations clearly perceivable by humans because of their distinct odor notes. It should be kept in mind, however, that the final flavor of a cheese cannot be considered simply the sum of individual VOC but rather arises from their interaction (masking, enhancement, or fusion among compounds) so that confirmation could derive only from specific sensory descriptions.

\section{Effects of Dietary CLA Supplement on the Flavor Profile of Ripened Cheese}

The addition of rumen-protected CLA to the diet of cows is known to strongly affect rumen and animal metabolism, and particularly fat metabolism (Schiavon et al., 2011; Shingfield et al., 2013; Petzold et al., 2013). Milk and cheese lipids are, in turn, important precursors of several cheese VOC. It worth noting that the addition of rpCLA to the TMR during the experiment (Schiavon et al., 2015) tended to reduce the cows' daily DMI $(-8.1 \% ; P=0.07)$ and daily ECM yield $(-6.5 \%$; $P=0.01)$, but not their efficiency $(+2.0 \%)$. Regarding milk quality, dietary CLA supplementation strongly affected the milk fat percentage $(-15.1 \% ; P<0.01)$ and daily production $(-8.8 \% ; P<0.01)$, and reduced daily protein production $(-3.5 \% ; P=0.04)$ but not milk protein percentage. Consequently, the protein-tofat ratio in the cheese was also modified, but in favor of the protein. Some CLA isomers, particularly C18:2 trans-10,cis-12, are known to inhibit de novo synthesis of fatty acids in the mammary gland of ruminants, causing depression of the milk fat percentage (Griinari et al., 1998; Shingfield et al., 2010), a decrease in shortto medium-chain odd SFA, and, conversely, a relative increase in long-chain UFA absorbed by the intestine or mobilized from body fat (Bauman et al., 2008; Pellattiero et al., 2015). We also observed these modifications in our experiment in both milk and ripened cheese (Schiavon et al., 2016).
During cheese ripening, the short-chain fatty acids may react with some sulfur compounds to form thioesters (Arora et al., 1995), which contribute to strong garlic, cabbage, and very ripe cheese odors (Bertuzzi et al., 2018). Unsaturated fatty acids mainly degrade to aldehyde by hydroperoxide, and the aldehyde then rapidly decomposes into acids and alcohols, whereas the SFA form ketones and then secondary alcohols (McSweeney and Sousa, 2000).

In our study, CLA supplementation increased the total amount of VOC, particularly acids and esters, but reduced the proportions of ketones and phenolics (Table 2), resulting in a potential decrease in the "base aroma" of cheese (qualitative LEF-1, Table 4). These changes to the cheese aroma may be due to the CLApromoted concentrations of long-chain fatty acids and alcohols, and also esters (McSweeney and Sousa, 2000). This caused a proportional decrease in some aldehydes (3-methylbutanal, hexanal, and benzaldehyde; Supplemental Table S2; https://doi.org/10.3168/jds.2019 -16495). 3-Methylbutanal and benzaldehyde originate, respectively, from the catabolism of leucine and phenylalanine (Bovolenta et al., 2014; Aprea et al., 2016), whereas hexanal is mainly formed by lipolysis (Engels et al., 1997). Another known source of 3-methylbutanal in dairy products is related to Strecker (Maillard) reactions (Smit et al., 2009). 3-Methylbutanal is reported to be a potent odor compound that can contribute a malt, oil, or butter aroma in different cheeses, whereas benzaldehyde and hexanal may contribute, respectively, almond and grass-herbaceous aromas (Curioni and Bosset, 2002).

The proportions of ketones and phenolics were dramatically decreased by dietary CLA addition, which is explained in part by the fact that 2-methylketones are obtained mainly from SFA (Collins et al., 2003). There was an approximately 2.5-fold decrease in 3-hydroxybutan-2-one, which is formed from galactose and glucose due to citrate metabolism (Snoep et al., 1992) and contributes to a buttery aroma (Cornu et al., 2009). $\delta$-Octalactone is generated from UFA by the action of lipoxygenases or hydratases (Dufosse et al., 1994) and may contribute to peach, apricot, and coconut odors in cheese (Bendall, 2001). In this study, the phenol family, which is responsible for putrid flavor (Badings et al., 1968), was also reduced by CLA addition.

The change in VOC profile observed here as a consequence of dietary supplementation with CLA increased the intensity of ripened cheese odor, but the strong modification of the proportions of many VOC and the reduction of those involved in the base cheese aroma need to be better evaluated through sensory description for a better understanding of the implications for the dairy industry in relation to consumer preference. 


\section{Effects of Dietary CP and CLA Interaction on the Flavor Profile of Ripened Cheese}

Interpreting the interaction between $\mathrm{CP}$ level and CLA addition in the diet is difficult and requires further research. Previous studies have shown that CLA supplementation exerts some protein-sparing effects (Park et al., 1997; Pariza et al., 2001; Schiavon et al., 2010) and, in our study, the low-CP diets with CLA supplementation increased $\mathrm{N}$ efficiency. Cabrita et al. (2007) showed that a reduction in CP level is related to an increase in the bioactivity of milk fatty acids, and it is interesting to note that this was significant, especially for the qualitative proportions of volatile alcohols and fatty acids, and for LEF-4 (butanol). Alcohol concentrations were particularly depressed in cheese made from the milk of cows fed the CP15 $\mathrm{CLA}$ diet, whereas the $\mathrm{CP} 12_{\text {CLA }}$ diet was associated with a decrease in acids. Acids are the most abundant VOC in ripened cheese and those with 4 to 12 carbons are important flavor components of many cheese types, contributing to their typical aroma (Curioni and Bosset, 2002). Alcohols result from the reduction of previously formed compounds (McSweeney, 2004) and contribute to fruity and green flavors (Thomsen et al., 2012).

\section{CONCLUSIONS}

The results of this study clearly show that, even though most VOC are produced during cheese ripening and are related to cheesemaking procedures, milk chemical composition, enzyme content, and native microflora (all of which are affected by the cows' feeding regimen and metabolism) have considerable effects on the fate of many VOC, and ultimately on the development of cheese flavor. Reducing dietary CP is one means to improve the efficiency of $\mathrm{N}$ metabolism and reduce $\mathrm{N}$ excretions into the environment, but it has been shown to affect the cheese volatilome (several alcohols, aldehydes, acids, esters, and terpenes), increasing quantitatively the latent explanatory factors "ethyl esters" and some "butan-" substances. Dietary rpCLA supplementation is thought to improve both the ecological footprint and the nutritional value of dairy products, although here, too, CLA addition affected the cheese volatilome. It increased the sum of all VOC released by the ripened cheese, particularly some acids and esters, and decreased the proportion of several alcohols, ketones, and phenolic substances ("base aroma" latent factor of cheese). The relationships between these changes and the sensory characteristics of cheese should be studied in future research to better understand the implications for the dairy industry and consumers.

\section{ACKNOWLEDGMENTS}

This work was financially supported by the Autonomous Province of Trento. We acknowledge SILA s.r.l. (Noale, VE, Italy) for providing the rumen-protected CLA. The authors greatly appreciate the technical assistance of the staff of the laboratory and the experimental farm.

\section{REFERENCES}

Agabriel, C., B. Martin, C. Sibra, J. C. Bonnefoy, M. C. Montel, R. Didienne, and S. Hulin. 2004. Effect of dairy production systems on the sensory characteristics of Cantal cheeses: A plantscale study. Anim. Res. 53:221-234. https://doi.org/10.1051/animres:2004013

Aprea, E., A. Romanzin, M. Corazzin, S. Favotto, E. Betta, F. Gasperi, and S. Bovolenta. 2016. Effects of grazing cow diet on volatile compounds as well as physicochemical and sensory characteristics of 12-month-ripened Montasio cheese. J. Dairy Sci. 99:6180-6190. https://doi.org/10.3168/jds.2016-10929.

Arora, G., F. Cormier, and B. Lee. 1995. Analysis of odor-active volatiles in cheddar cheese headspace by multidimensional GC/MS/ sniffing. J. Agric. Food Chem. 43:748-752. https://doi.org/10 .1021/jf00051a035.

Arriola Apelo, S. I., A. L. Bell, K. Estes, J. Ropelewski, M. J. de Veth, and M. D. Hanigan. 2014. Effects of reduced dietary protein and supplemental rumen-protected essential amino acids on the nitrogen efficiency of dairy cows. J. Dairy Sci. 97:5688-5699. https:// doi.org/10.3168/jds.2013-7833.

Badings, H. T., J. Stadhouders, and H. Van Duin. 1968. Phenolic flavor in cheese. J. Dairy Sci. 51:31-35. https://doi.org/10.3168/jds .S0022-0302(68)86914-0.

Bauman, D. E., J. W. Perfield II, K. J. Harvatine, and L. H. Baumgard. 2008. Regulation of fat synthesis by conjugated linoleic acid: Lactation and the ruminant model. J. Nutr. 138:403-409. https:// doi.org/10.1093/jn/138.2.403.

Bendall, J. G. 2001. Aroma compounds of fresh milk from New Zealand cows fed different diets. J. Agric. Food Chem. 49:4825-4832. https://doi.org/10.1021/jf010334n.

Bergamaschi, M., E. Aprea, E. Betta, F. Biasioli, C. Cipolat-Gotet, A Cecchinato, G. Bittante, and F. Gasperi. 2015a. Effects of dairy system, herd within dairy system, and individual cow characteristics on the volatile organic compound profile of ripened model cheeses. J. Dairy Sci. 98:2183-2196. https://doi.org/10.3168/jds 2014-8807.

Bergamaschi, M., F. Biasioli, L. Cappellin, A. Cecchinato, C. CipolatGotet, A. Cornu, F. Gasperi, B. Martin, and G. Bittante. 2015b. Proton transfer reaction time-of-flight mass spectrometry: A highthroughput and innovative method to study the influence of dairy system and cow characteristics on the volatile compound fingerprint of cheeses. J. Dairy Sci. 98:8414-8427. https://doi.org/10 .3168/jds.2015-9803.

Bergamaschi, M., and G. Bittante. 2018. From milk to cheese: Evolution of flavor fingerprint of milk, cream, curd, whey, ricotta, scotta, and ripened cheese obtained during summer Alpine pasture. J. Dairy Sci. 101:3918-3934. https://doi.org/10.3168/jds.2017-13573.

Bergamaschi, M., A. Cecchinato, F. Biasioli, F. Gasperi, B. Martin, and G. Bittante. 2016. From cow to cheese: genetic parameters of the flavour fingerprint of cheese investigated by direct injection mass spectrometry (PTR-ToF-MS). Genet. Sel. Evol. 48:89. https: //doi.org/10.1186/s12711-016-0263-4.

Bertuzzi, A. S., P. L. H. McSweeney, M. C. Rea, and K. N. Kilcawley. 2018. Detection of volatile compounds of cheese and their contribution to the flavor profile of surface-ripened cheese. Compr. Rev. Food Sci. Food Saf. 17:371-390. https://doi.org/10.1111/ 1541-4337.12332. 
Bittante, G., A. Cecchinato, N. Cologna, M. Penasa, F. Tiezzi, and M. De Marchi. 2011a. Factors affecting the incidence of first-quality wheels of Trentingrana cheese. J. Dairy Sci. 94:3700-3707. https:/ /doi.org/10.3168/jds.2010-3746.

Bittante, G., N. Cologna, A. Cecchinato, M. De Marchi, M. Penasa, F. Tiezzi, I. Endrizzi, and F. Gasperi. 2011b. Monitoring of sensory attributes used in the quality payment system of Trentingrana cheese. J. Dairy Sci. 94:5699-5709. https://doi.org/10.3168/jds $.2011-4319$

Bovolenta, S., A. Romanzin, M. Corazzin, M. Spanghero, E. Aprea, F. Gasperi, and E. Piasentier. 2014. Volatile compounds and sensory properties of Montasio cheese made from the milk of Simmental cows grazing on alpine pastures. J. Dairy Sci. 97:7373-7385. https: //doi.org/10.3168/jds.2014-8396.

Cabrita, A. R. J., R. J. B. Bessa, S. P. Alves, R. J. Dewhurst, and A. J. M. Fonseca. 2007. Effects of dietary protein and starch on intake, milk production, and milk fatty acid profiles of dairy cows fed corn silage-based diets. J. Dairy Sci. 90:1429-1439. https://doi.org/10 .3168/jds.S0022-0302(07)71628-4.

Calder, P. C. 2015. Functional roles of fatty acids and their effects on human health. JPEN J. Parenter. Enteral. Nutr. 39:18S-32S. https://doi.org/10.1177/0148607115595980.

Carpino, S., S. Mallia, S. La Terra, C. Melilli, G. Licitra, T. E. Acree, D. M. Barbano, and P. J. Van Soest. 2004. Composition and aroma compounds of Ragusano cheese: Native pasture and total mixed rations. J. Dairy Sci. 87:816-830. https://doi.org/10.3168/ jds.S0022-0302(04)73226-9.

Chin, S. F., W. Liu, J. M. Storkson, Y. L. Ha, and M. W. Pariza. 1992. Dietary sources of conjugated dienoic isomers of linoleic acid, a newly recognized class of anticarcinogens. J. Food Compos. Anal. 5:185-197. https://doi.org/10.1016/0889-1575(92)90037-K.

Cipolat-Gotet, C., A. Cecchinato, M. A. Drake, A. Marangon, B. Martin, and G. Bittante. 2018. From cow to cheese: Novel phenotypes related to the sensory profile of model cheeses from individual cows. J. Dairy Sci. 101:5865-5877. https://doi.org/10.3168/jds .2017-14342.

Coakley, M., E. Barrett, J. J. Murphy, R. P. Ross, R. Devery, and C. Stanton. 2007. Cheese manufacture with milk with elevated conjugated linoleic acid levels caused by dietary manipulation. J. Dairy Sci. 90:2919-2927. https://doi.org/10.3168/jds.2006-584.

Collins, Y. F., P. L. H. McSweeney, and M. G. Wilkinson. 2003. Lipolysis and free fatty acid catabolism in cheese: A review of current knowledge. Int. Dairy J. 13:841-866. https://doi.org/10.1016/ S0958-6946(03)00109-2.

Cornu, A., N. Rabiau, N. Kondjoyan, I. Verdier-Metz, P. Pradel, P. Tournayre, J. L. Berdagué, and B. Martin. 2009. Odour-active compound profiles in Cantal-type cheese: Effect of cow diet, milk pasteurization and cheese ripening. Int. Dairy J. 19:588-594. https: //doi.org/10.1016/j.idairyj.2009.04.008.

Coulon, J.-B., A. Delacroix-Buchet, B. Martin, and A. Pirisi. 2004 Relationships between ruminant management and sensory characteristics of cheeses: A review. Lait 84:221-241. https://doi.org/10 .1051/lait:2004008.

Curioni, P. M. G., and J. O. Bosset. 2002. Key odorants in various cheese types as determined by gas chromatography-olfactometry. Int. Dairy J. 12:959-984. https://doi.org/10.1016/S0958 -6946(02)00124-3.

Drake, M. A. 2007. Invited review: Sensory analysis of dairy foods. J. Dairy Sci. 90:4925-4937. https://doi.org/10.3168/jds.2007-0332.

Dufosse, L., A. Latrasse, and H. E. Spinnler. 1994. Importance of lactones in food flavours: structure, distribution, sensory properties and biosynthesis. Sci. Aliments 14:17-50.

Engels, W. J. M., R. Dekker, C. de Jong, R. Neeter, and S. Visser. 1997. A comparative study of volatile compounds in the watersoluble fraction of various types of ripened cheese. Int. Dairy J. 7:255-263. https://doi.org/10.1016/S0958-6946(97)00003-4.

Fanchone, A., P. Nozière, J. Portelli, B. Duriot, V. Largeau, and M. Doreau. 2013. Effects of nitrogen underfeeding and energy source on nitrogen ruminal metabolism, digestion, and nitrogen partitioning in dairy cows. J. Anim. Sci. 91:895-906. https://doi.org/10 $.2527 /$ jas.2012-5296.
FASS. 2010. Guide for the Care and Use of Agricultural Animals in Research and Teaching. 3rd ed. Federation of Animal Science Societies, Champaign, IL.

Ferlay, A., L. Bernard, A. Meynadier, and C. Malpuech-Brugère. 2017. Production of trans and conjugated fatty acids in dairy ruminants and their putative effects on human health: A review. Biochimie 141:107-120. https://doi.org/10.1016/j.biochi.2017.08.006.

Frank, D. C., C. M. Owen, and J. Patterson. 2004. Solid phase microextraction (SPME) combined with gas-chromatography and olfactometry-mass spectrometry for characterization of cheese aroma compounds. Lebensm. Wiss. Technol. 37:139-154. https://doi.org/ 10.1016/S0023-6438(03)00144-0.

Griinari, J. M., D. A. Dwyer, M. A. McGuire, D. E. Bauman, D. L. Palmquist, and K. V. V. Nurmela. 1998. Trans-octadecenoic acids and milk fat depression in lactating cows. J. Dairy Sci. 81:12511261. https://doi.org/10.3168/jds.S0022-0302(98)75686-3.

Hassan, F. A. M., M. A. M. Abd El-Gawad, and A. K. Enab. 2012 Flavour compounds in cheese. Int. J. Acad. Res. 4:169-181.

Hennessy, A. A., P. R. Ross, G. F. Fitzgerald, and C. Stanton. 2016. Sources and bioactive properties of conjugated dietary fatty acids. Lipids 51:377-397. https://doi.org/10.1007/s11745-016-4135-z.

Huhtanen, P., and A. N. Hristov. 2009. A meta-analysis of the effects of dietary protein concentration and degradability on milk protein yield and milk N efficiency in dairy cows. J. Dairy Sci. 92:32223232. https://doi.org/10.3168/jds.2008-1352.

IDF (International Dairy Federation). 2018. The World Dairy Situation 2018. Bulletin 494/2018. International Dairy Federation, Brussels, Belgium.

Leonardi, C., M. Stevenson, and L. E. Armentano. 2003. Effect of two levels of crude protein and methionine supplementation on performance of dairy cows. J. Dairy Sci. 86:4033-4042. https://doi.org/ 10.3168/jds.S0022-0302(03)74014-4.

Li, K., A. J. Sinclair, F. Zhao, and D. Li. 2018. Uncommon fatty acids and cardiometabolic health. Nutrients 10:1559. https://doi.org/10 $.3390 /$ nu10101559.

Liu, S.-Q., R. Holland, and V. L. Crow. 1998. Ethyl butanoate formation by dairy lactic acid bacteria. Int. Dairy J. 8:651-657. https:/ /doi.org/10.1016/S0958-6946(98)00100-9.

Liu, S. Q., R. Holland, and V. L. Crow. 2004. Esters and their biosynthesis in fermented dairy products: A review. Int. Dairy J. 14:923945. https://doi.org/10.1016/j.idairyj.2004.02.010.

Marilley, L., and M. G. Casey. 2004. Flavours of cheese products: Metabolic pathways, analytical tools and identification of producing strains. Int. J. Food Microbiol. 90:139-159. https://doi.org/10 .1016/s0168-1605(03)00304-0.

McSweeney, P. L. H. 2004. Biochemistry of cheese ripening. Int. J. Food Microbiol. 57:127-144. https://doi.org/10.1111/j.1471-0307 2004.00147.x.

McSweeney, P. L. H., and M. J. Sousa. 2000. Biochemical pathways for the production of flavour compounds in cheeses during ripening: A review. Lait 80:293-324. https://doi.org/10.1051/lait:2000127.

Molimard, P., and H. E. Spinnler. 1996. Review: Compounds involved in the flavor of surface mold-ripened cheeses: Origins and properties. J. Dairy Sci. 79:169-184. https://doi.org/10.3168/jds.S0022 $-0302(96) 76348-8$.

Notarnicola, B., G. Tassielli, P. A. Renzulli, V. Castellani, and S. Sala. 2017. Environmental impacts of food consumption in Europe. J. Clean. Prod. 140:753-765. https://doi.org/10.1016/j.jclepro.2016 .06 .080 .

NRC. 2001. Nutrient Requirements of Dairy Cattle. 7th rev. ed. Natl Acad. Press, Washington, DC.

O'Callaghan, T. F., D. T. Mannion, D. Hennessy, S. McAuliffe, M. G. O'Sullivan, N. Leeuwendaal, T. P. Beresford, P. Dillon, K. N. Kilcawley, J. J. Sheehan, R. P. Ross, and C. Stanton. 2017. Effect of pasture versus indoor feeding systems on quality characteristics, nutritional composition, and sensory and volatile properties of fullfat Cheddar cheese. J. Dairy Sci. 100:6053-6073. https://doi.org/ 10.3168/jds.2016-12508.

Pariza, M. W., Y. Park, and M. E. Cook. 2001. The biologically active isomers of conjugated linoleic acid. Prog. Lipid Res. 40:283-298. https://doi.org/10.1016/S0163-7827(01)00008-X. 
Park, Y., K. J. Albright, W. Liu, J. M. Storkson, M. E. Cook, and M. W. Pariza. 1997. Effect of conjugated linoleic acid on body composition in mice. Lipids 32:853-858. https://doi.org/10.1007/ s11745-997-0109-x.

Pegolo, S., M. Bergamaschi, F. Gasperi, F. Biasioli, A. Cecchinato, and G. Bittante. 2018. Integrated PTR-ToF-MS, GWAS and biological pathway analyses reveal the contribution of cow's genome to cheese volatilome. Sci. Rep. 8:17002. https://doi.org/10.1038/ s41598-018-35323-5.

Pellattiero, E., A. Cecchinato, F. Tagliapietra, S. Schiavon, and G. Bittante. 2015. The use of 2-dimensional gas chromatography to investigate the effect of rumen-protected conjugated linoleic acid, breed, and lactation stage on the fatty acid profile of sheep milk. J. Dairy Sci. 98:2088-2102. https://doi.org/10.3168/jds.2014-8395.

Perfield, J. W. Ii., G. Bernal-Santos, T. R. Overton, and D. E. Bauman. 2002. Effects of dietary supplementation of rumen-protected conjugated linoleic acid in dairy cows during established lactation. J. Dairy Sci. 85:2609-2617. https://doi.org/10.3168/jds.S0022 $-0302(02) 74346-4$

Petzold, M., U. Meyer, S. Kersten, J. Spilke, R. Kramer, G. Jahreis, and S. Dänicke. 2013. Effect of conjugated linoleic acids and dietary concentrate proportion on performance, milk composition, milk yield and metabolic parameters of periparturient dairy cows. Arch. Anim. Nutr. 67:185-201. https://doi.org/10.1080/1745039X .2013.793049.

Qian, M., and G. Reineccius. 2002. Identification of aroma compounds in Parmigiano-Reggiano cheese by gas chromatography/olfactometry. J. Dairy Sci. 85:1362-1369. https://doi.org/10.3168/jds.S0022 -0302(02)74202-1.

Schiavon, S., G. Cesaro, A. Cecchinato, C. Cipolat-Gotet, F. Tagliapietra, and G. Bittante. 2016. The influence of dietary nitrogen reduction and conjugated linoleic acid supply to dairy cows on fatty acids in milk and their transfer to ripened cheese. J. Dairy Sci. 99:8759-8778. https://doi.org/10.3168/jds.2016-11371.

Schiavon, S., G. Cesaro, F. Tagliapietra, L. Gallo, and G. Bittante. 2015. Influence of N shortage and conjugated linoleic acid supplementation on some productive, digestive, and metabolic parameters of lactating cows. Anim. Feed Sci. Technol. 208:86-97. https: //doi.org/10.1016/j.anifeedsci.2015.07.016.

Schiavon, S., M. De Marchi, F. Tagliapietra, L. Bailoni, A. Cecchinato, and G. Bittante. 2011. Effect of high or low protein ration combined or not with rumen protected conjugated linoleic acid (CLA) on meat CLA content and quality traits of double-muscled Piemontese bulls. Meat Sci. 89:133-142. https://doi.org/10.1016/ j.meatsci.2011.03.025.

Schiavon, S., F. Tagliapietra, G. Dalla Montà, A. Cecchinato, and G. Bittante. 2012. Low protein diets and rumen-protected conjugated linoleic acid increase nitrogen efficiency and reduce the environmental impact of double-muscled young Piemontese bulls. Anim. Feed Sci. Technol. 174:96-107. https://doi.org/10.1016/j .anifeedsci.2012.02.011
Schiavon, S., F. Tagliapietra, M. Dal Maso, L. Bailoni, and G. Bittante. 2010. Effects of low-protein diets and rumen-protected conjugated linoleic acid on production and carcass traits of growing double-muscled Piemontese bull. J. Anim. Sci. 88:3372-3383. https://doi.org/10.2527/jas.2009-2558.

Schiavon, S., F. Tagliapietra, S. Pegolo, G. Cesaro, A. Cecchinato, and G. Bittante. 2018. Effect of dietary protein level and conjugated linoleic acid supply on milk secretion and fecal excretion of fatty acids. Anim. Feed Sci. Technol. 245:10-19. https://doi.org/ 10.1016/j.anifeedsci.2018.08.013.

Shingfield, K. J. L. Bernard, C. Leroux, and Y. Chilliard. 2010. Role of trans fatty acids in the nutritional regulation of mammary lipogenesis in ruminants. Animal 4:1140-1166. https://doi.org/10 .1017/S1751731110000510.

Shingfield, K. J., M. Bonnet, and N. D. Scollan. 2013. Recent developments in altering the fatty acid composition of ruminant-derived foods. Animal 7(Suppl. 1):132-162. https://doi.org/10.1017/ S1751731112001681.

Smit, B. A., W. J. M. Engels, and G. Smit. 2009. Branched chain aldehydes: Production and breakdown pathways and relevance for flavour in foods. Appl. Microbiol. Biotechnol. 81:987-999. https:// doi.org/10.1007/s00253-008-1758-x.

Smit, G., B. A. Smit, and W. J. M. Engels. 2005. Flavour formation by lactic acid bacteria and biochemical flavour profiling of cheese products. FEMS Microbiol. Rev. 29:591-610. https://doi.org/10 .1016/j.fmrre.2005.04.002.

Snoep, J. L., M. T. De Mattos, M. J. Starrenburg, and J. Hugenholtz. 1992. Isolation, characterization, and physiological role of the pyruvate dehydrogenase complex and alpha-acetolactate synthase of Lactococcus lactis ssp. lactis bv. diacetylactis. J. Bacteriol. 174:4838-4841. https://doi.org/10.1128/jb.174.14.4838-4841.1992.

Thomsen, M., C. Martin, F. Mercier, P. Tournayre, J. L. Berdagué, T. Thomas-Danguin, and E. Guichard. 2012. Investigating semihard cheese aroma: Relationship between sensory profiles and gas chromatography-olfactometry data. Int. Dairy J. 26:41-49. https:/ /doi.org/10.1016/j.idairyj.2012.04.009.

Vialloninsta, C., B. Martin, I. Verdier-Metz, P. Pradel, J.-P. Garel, J.-B. Coulon, and J.-L. Berdagué. 2000. Transfer of monoterpenes and sesquiterpenes from forages into milk fat. Lait 80:635-641. https://doi.org/10.1051/lait:2000150.

\section{ORCIDS}

Flavia Gasperi @ https://orcid.org/0000-0003-0055-9464 Eugenio Aprea ๑ https://orcid.org/0000-0003-3648-0459 Matteo Bergamaschi ๑ https://orcid.org/0000-0002-3983-5019 Franco Tagliapietra (ㄴ) https://orcid.org/0000-0002-0593-1600 Stefano Schiavon (1) https://orcid.org/0000-0002-5539-8947 Giovanni Bittante @ https://orcid.org/0000-0001-7137-7049 